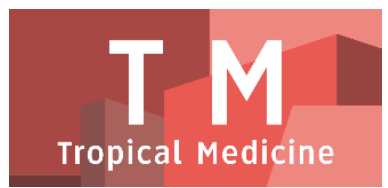

PAPER - OPEN ACCESS

\title{
Pengalaman Anak Usia Sekolah Dengan Leukemia Yang Dirawat di Rumah Sakit Kota Medan: Studi Fenomenologi
}

Author : Masita Ruth Irene Lumbantoruan

DOI $\quad: 10.32734 / \mathrm{tm} . v 1 i 1.41$

Paper Page : $80-86$

Volume 1 Issue 1 - 2018 TALENTA Conference Series: Tropical Medicine (TM)

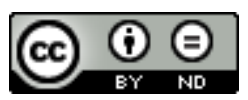

This work is licensed under a Creative Commons Attribution-NoDerivatives 4.0 International License.

Published under licence by TALENTA Publisher, Universitas Sumatera Utara
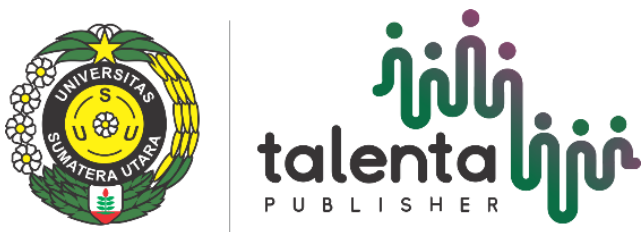


\title{
i talentaljọ TALENTA Conference Series
}

Available online at https://talentaconfseries.usu.ac.id

\section{Pengalaman Anak Usia Sekolah Dengan Leukemia Yang Dirawat di Rumah Sakit Kota Medan: Studi Fenomenologi}

\author{
Masita Ruth Irene Lumbantoruan ${ }^{\mathrm{a}, *}$ dan Dewi Elizadiani Suza ${ }^{\mathrm{a}}$ \\ ${ }^{a}$ Fakultas Keperawatan, Universitas Sumatera Utara, Medan 20155
}

Email: masitaril@gmail.com, dewi1@usu.ac.id, elizadiani@hotmail.com

\begin{abstract}
Abstrak
Salah satu jenis kanker yang paling banyak didiagnosa pada anak dan remaja adalah leukemia dimana pengobatannya membutuhkan waktu yang lama dan berulang di rumah sakit. Penderita leukemia semasa anak-anak banyak terdiagnosa pada usia 0-14 tahun yang diantaranya adalah anak usia sekolah yaitu 612 tahun. Tujuan penelitian ini adalah untuk menggali pengalaman anak usia sekolah dengan leukemia yang dirawat di rumah sakit kota Medan. Penelitian ini menggunakan metode kualitatif fenomenologi dengan wawancara mendalam kepada anak usia sekolah. Teknik pengambilan sampel yang digunakan adalah purposive sampling dengan jumlah partisipan sebanyak tujuh orang partisipan yang memiliki kriteria inklusi sebagai berikut: 1) anak usia sekolah 7-12 tahun, 2) dirawat di rumah sakit dengan diagnosa leukemia yang sedang menjalani minimal 3 hari perawatan, 3) komunikatif, 4) bersedia menjadi partisipan yang dinyatakan secara verbal atau dengan menandatangani surat perjanjian penelitian. Hasil wawancara dianalisis dengan metode Giorgi. Data yang sudah dianalisis memunculkan 5 tema, yaitu: 1) anak mengalami penderitaan fisik, 2) anak mengalami penderitaan psikis, 3) anak kehilangan waktu aktivitas, 4) anak mengalami perubahan lingkungan sosial, 5) anak mendapatkan dukungan keluarga. Hasil penelitian ini memperlihatkan bahwa seluruh partisipan yang merupakan anak usia sekolah dengan leukemia yang dirawat di rumah sakit kota Medan mengalami stresor hospitalisasi yang disebabkan oleh tindakan pengobatan, kondisi penyakit, serta perawatan yang membutuhkan waktu lama dan berulang. Diharapkan bagi pelayanan rumah sakit agar memperhatikan tahap tumbuh kembang anak selama masa perawatan, khususnya dalam menciptakan lingkungan yang nyaman, pemberian terapi psikologis dan nutrisi yang sesuai dengan kebutuhan anak.
\end{abstract}

Kata Kunci: anak usia sekolah; leukimia

\section{Pendahuluan}

Salah satu jenis kanker yang paling banyak didiagnosa pada anak dan remaja adalah leukemia (National Cancer Institute, 2015). Leukemia adalah penyakit keganasan pada sel darah yang berasal dari sumsum tulang [6]. Pengobatan leukemia memiliki tahapan-tahapan yang mengharuskan anak untuk dirawat di rumah sakit dalam waktu yang cukup lama dan berulang [2] Beberapa lembaga kesehatan yang khusus memperhatikan kanker dan hasil penelitian yang dilakukan oleh Sulastriana, [4] menyatakan bahwa anak yang mengidap leukemia akut rata-rata terdiagnosa pada rentang usia 0-14 tahun, yang diantaranya adalah anak usia sekolah yaitu usia 6-12 tahun (11]

Anak dengan usia 6-12 tahun adalah anak yang mulai memasuki dunia sekolah atau sering disebut dengan anak usia sekolah. Pada usia ini, anak menghabiskan lebih banyak waktu di sekolah atau melakukan hal-hal akademis 
yang terkait. Ini berarti sekolah dan hal-hal terkait adalah lingkungan yang sangat penting dalam hidup anak [8]. Menurut Hurlock [4], pada usia sekolah, anak memasuki tugas perkembangan yang berbeda dari tahap usia sebelumnya (pra sekolah). Pada usia ini anak akan mulai belajar bersosialisasi, belajar memainkan perannya di masyakat, belajar memperoleh kebebasan yang bersifat pribadi, mengembangkan sikap positif dan lainnya.

Beberapa orangtua menyatakan bahwa kebanyakan anak menunjukkan perilaku dan suasana hati yang cukup rumit. Hal ini disebabkan stresor yang terkait kanker dan terapinya yang sangat banyak seperti prosedur medis (jarum, pungsi lumbar, pemerikasaan tulang belakang), efek kemoterapi (nyeri, kelemahan, mual dan muntah), kehilangan kontrol diri, hospitalisasi, infeksi, terisolasi dari teman, aktivitas normal menjadi kacau yang salah satunya adalah tidak dapat pergi ke sekolah [10]

Peristiwa tersebut dapat mempengaruhi cara anak memandang dirinya sendiri dan lingkungannya, bahkan berdampak ketika anak tersebut sudah pulang ke rumah, baik dampak positif maupun negatif [2]. Penyakit kronis seperti kanker bahkan merupakan salah satu penyebab masalah kesehatan mental pada anak usia sekolah [5].

Beberapa hal yang mungkin dirasakan anak usia sekolah menurut American Cancer Society [1] adalah merasa sedih karena kegiatan sekolah terganggu, ingin bertemu teman sekelas, marah dan kesedihan akibat kehilangan kehidupan normalnya, merasa bersalah, takut dan cemas, dan mencari dukungan emosional dan sosial dari keluarga dan teman. Penanganan yang diharapkan tidak hanya berfokus pada penyembuhan kankernya namun juga bagaimana dapat memenuhi kebutuhan-kebutuhan anak secara holistik yang kemudian berpengaruh baik pada tumbuh kembangnya. Seperti yang dijelaskan oleh Wanda dan Hayati dalam penelitian tentang pengalaman anak usia sekolah pasca rawat inap, dampak negatif yang dialami anak selama menjalani perawatan di rumah sakit perlu diminimalkan agar anak mampu bertahan dan tetap dapat mencapai tugas perkembangannya.

Penelitian ini dimaksudkan untuk menggali pengalaman anak usia sekolah yang dirawat di rumah sakit, khususnya kota Medan. Pengalaman yang diceritakan langsung oleh anak semasa menjalani terapi akan sangat membantu untuk mengetahui kebutuhan anak secara biologis, psikologis, sosiologis, dan spiritual.

\section{Metode Penelitian}

\subsection{Desain Penelitian}

Penelitian ini merupakan penelitian kualitatif dengan pendekatan fenomenologi yang menekankan pada deskripsi pengalaman partisipan, dimana dalam penelitian ini adalah pengalaman anak usia sekolah dengan leukemia yang dirawat di rumah sakit kota Medan yang kemudian akan dideskripsikan [7].

\subsection{Partisipan}

Partisipan penelitian ini adalah anak usia sekolah yang mengalami leukemia dan dirawat di rumah sakit kota Medan dengan jumlah 7 orang partisipan. Pemilihan partisipan dalam penelitian ini dilakukan dengan menggunakan metode purposive sampling dengan kriteria inklusi: 1) Anak usia sekolah dengan rentang usia 7-12, 2) dirawat dirumah sakit kota Medan dengan diagnosa leukemia yang sedang menjalani perawatan minimal 3 hari, 3) komunikatif, dan 4) bersedia menjadi partisipan yang dinyatakan secara verbal atau dengan menandatangani surat perjanjian penelitian.

\subsection{Teknik Pengumpulan Data}

Partisipan diberi penjelasan tentang penelitian dan tujuannya terlebih dahulu lalu meminta kesediaan menjadi partisipan. Orangtua dari anak yang bersedia menjadi partisipan dilibatkan untuk mengisi lembar persetujuan yang kemudian ditandatangani. Peneliti melakukan kontrak waktu dan tempat untuk melakukan indepth interview yang direkam dimana sebelumnya penelitia dan partisipan melalui proses prolonged engagement. Wawancara dilakukan dengan menggunakan pertanyaan terbuka yang memfasilitasi respon terkait pertanyaan seputar pengalaman anak tersebut dalam masa perawatannya. Untuk memperoleh hasil penelitian yang dapat dipercaya maka data divalidasi dengan beberapa kriteria, yaitu credibility, confirmability, transferability, dependability, dan Authenticity [7] 


\subsection{Teknik Analisis Data}

Data yang diperoleh dari partisipan saat wawancara direkam menggunakan perekam suara dan dibuat transkrip secara verbatim. Setelah itu dianalisis dengan metode Giorgi.

\section{Hasil Penelitian}

Hasil penelitian ini mendapatkan 5 tema terkait pengalaman anak usia sekolah dengan leukemia yang dirawat di rumah sakit kota Medan, yaitu: 1) mengalami pendertitaan fisik, 2) mengalami penderitaan psikis, 3) kehilangan waktu aktifitas, 4) mengalami perubahan lingkungan sosial, dan 5) mendapatkan dukungan keluarga.

\subsection{Mengalami Penderitaan Fisik}

Partisipan dalam penelitian ini mengalami penderitaan penderitaan fisik yang disebabkan oleh pengobatan leukemia dan efek penyakit. Tindakan pengobatan yang dilakukan partisipan terdiri dari pemeriksaan fisik dan penunjang, mendapatkan kemoterapi, dan mendapatkan transfusi darah yang menyebabkan perlukaan tubuh. Partisipan juga merasakan efek penyakit yang menyebabkan rasa tidak nyaman dan kesakitan.

"ni inilah dari sini (lengan) cek darah, em... BMP dari punggung” (P3)

"Langsung transfusi...10 kantong masuk darahnya." (P4)

"Bahuku sakit. Ngilu dia kayak mau copot... sakit perutku. Baru ada bisul bisulnya besar di badanku."

(P5)

"Sakit semua.. sudah delapan bulan kekgini" (P6)

"kalau satu vinkristin, MTX oral, yang disuntik dari belakang itu MTX IT...sakit disuntik obat yang dipunggung” (P7)

\subsection{Mengalami Penderitaan Psikis}

Partisipan juga mengalami berbagai penderitaan psikis selama menjalani pengobatan di rumah sakit yang berupa takut dengan jarum suntik, sedih melihat orang tua, tidak suka suasana rumah sakit, dan merasa bosan.

"Paling bikin takut em.. BMP. Kan.. ntah kekmana nanti. Ntah pendarahan. Soalnya kan pernah." (P3) "Sedih sebenarnya. Mamak yang pas datang sama bapak pas aku sakit parah nangis dia. Padahal mamak disitu baru melahirkan gak boleh stres karena abis operasi. Jadi pas itu gak dikasih tau aku sakit apa." (P7)

"Banyak orang. Berisik. Banyak nangis anak-anak...sakit kepalaku” (P6)

“Bosen.. nggak ada (ngapa-ngapain). Diam-diam aja." (P4)

\subsection{Kehilangan Waktu Aktifitas}

Partisipan yang dirawat di rumah sakit menyatakan ia tidak lagi dapat melakukan berbagai aktifitas dan kebiasaan lainnya seperti sebelum mengalami perawatan intens. Hal-hal yang hilang dari partisipan atau yang tidak lagi dapat ia lakukan seperti sedia kala adalah tidak melakukan rutinitas, tidak bebas bergerak, membatasi aktifitas dan jenis makanan.

“Gak pernah lagi sekolah selama di medan. Udah permisi sama ibuk guru.” (P4)

"Nggak ada kubawa buku kesini. Buku dari sekolah gak bisa dibawa ke rumah tapi dipulangkan. Kalau gak sekolah gak bisalah aku belajar." (P6)

"Em.. gak bisalah main-main. Gaenak dia (selang infus) nanti nyangkot-nyangkot" (P5)

"nggak boleh (makan) saos, bakso, yang pengawet” (P1) 


\subsection{Mengalami Perubahan Lingkungan Sosial}

Sepanjang perawatannya di rumah sakit, partisipan mengalami perubahan dari lingkungan sosialnya. Perubahan ini terjadi pada sikap teman dan orangtuanya dimana mereka adalah orang terdekat anak. Partisipan juga terlibat interaksi sosial yang cukup dekat dengan beberapa tenaga medis.

"Kawan-kawanlah berubah... kalau dulu sering musuhin. Orang itu jadi baek” (P2)

"Kalau berobat kesini jadi gak bisa mama bekerja. Gak bisa pergi ke kebun. Kalau dulu sama ayah pergi orang itu ngapain sawit." (P6)

"main main sama kawan yang di rumah sakit juga" (P7)

"baik (dokternya). Mau bicara-bicara sama dokternya. Kalau masukin obat, bisa cerita dulu” (P6)

\subsection{Mendapatkan Dukungan Keluarga}

Dalam masa perawatan, keluarga adalah orang-orang yang paling sering bersama dengan partisipan. Beberapa dukungan yang diterima anak dari keluarga selama masa perawatan berbentuk seperti dikunjungi keluarga, didampingi orang tua dan, dirawat ibu.

\section{Pembahasan}

\subsection{Mengalami Penderitaan Fisik}

Pengobatan leukemia yang terdiri dari berbagai prosedur invasi membuat partisipan mengalami rasa nyeri dan ketidaknyamanan. Proses pengobatan dimulai dari adanya pemeriksaan fisik dan pemeriksaan penunjang. Pemeriksaan ini tidak hanya bertujuan untuk menentukan diagnosa saja namun juga perlu dalam melihat keberhasilan dan perencanaan perawatan selanjutnya (Sudoyo, et al., 2010), sehingga anak akan berulang kali mengalaminya selama proses pengobatan.

Berdasarkan hasil wawancara, rasa nyeri yang dirasakan, khususnya pada saat pemasangan infus, lebih menonjol pada masa-masa awal pengobatan dan mulai terbiasa seiring berjalannya waktu. Sposito et al. (2015) dalam penelitiannya juga menemukan hal tersebut, dimana hal ini diidentifikasi sebagai bentuk rasa bertahan dalam rasa tidak nyaman selama proses pengobatan karena menyadari bahwa itu satu-satunya harapan untuk segera sembuh dan harus melewatinya. Anak usia sekolah mampu menahan rasa sakit ini karena mereka memiliki harapan kuat untuk sembuh.

Penderitaan fisik yang selanjutnya dirasakan anak disebabkan oleh efek kemoterapi dan efek dari penyakitnya. Partisipan menyatakan mengalami bentuk alergi seperti bisul, pembengkakan sendi, suhu tubuh meningkat, nyeri perut, penurunan $\mathrm{Hb}$, dan mengalami perdarahan. Secara sadar, partisipan mengatakan bahwa mereka memang mengalami dampak penyakitnya. Sel leukemi yang menginfiltrasi ke organ-organ lain akan menyebabkan fungsi normal organ tersebut akan terganggu dan beberapa diantaranya ditandai dengan adanya pembengkakan pada organ tersebut. Infiltrasi ini juga menyebabkan rasa ngilu atau tidak nyaman pada anggota gerak, pembengkakan karena alergi ataupun infeksi [1]

Kemoterapi merupakan terapi utama yang dijalani anak untuk mengatasi dampak dari penyakit leukemia yang mereka derita, namun menyebabkan efek samping seperti mual muntah, perubahan indra pengecapan dan penghidu, kelemahan, kelelahan, rambut rontok, kehilangan berat badan, mulut kering, konstipasi, dan diare. Menurut studi Rheingans (2008) dalam Sposito et al. (2015) anak mengingat bahwa mual dan muntah adalah efek samping yang paling sulit untuk diatasi selama masa pengobatan, sehingga pemenuhan nutrisi yang tepat dan adekuat sangat dibutuhkan. Anemia dan trombositopenia kemudian merupakan komplikasi tersering yang dialami dan mengharuskan anak untuk mendapatkan transfusi darah berulang kali.

Anak juga harus mengahadapi adanya perubahan fisik akibat kemoterapi. Beberapa partisipan menyikapinya dengan respon yang adaptif. Sposito, et al. (2015) menyatakan selama masa pengobatan kanker, anak usia sekolah menunjukkan pola-pola koping yang memampukan mereka bertahan pada saat menjalani perawatan. 


\subsection{Mengalami Penderitaan Psikis}

Partisipan yang diwawancarai juga menyatakan adanya bentuk penderitaan psikis yang mereka alami seperti rasa takut terhadap jarum suntik, sedih melihat orang tua, tidak suka suasana rumah sakit dan merasa bosan.

Rasa takut yang diungkapkan partisipan terhadap prosedur tindakan yang menggunakan jarum suntik terjadi pada masa awal perawatannya, namun beberapa tindakan perawatan lainnya seperti pemeriksaan sumsum tulang dan pemberian kemoterapi intratekal masih menyisakan rasa takut pada partisipan meskipun sudah menjalani perawatan yang sama berulang kali. Hal ini disebabkan karena anak sangat takut dengan apa yang akan terjadi saat dia tertidur. Bila memperhatikan tahapan tumbuh kembang anak, anak usia prasekolah takut terhadap masker atau lingkungan yang asing, sedangkan anak usia sekolah merasa takut terhadap apa yang akan terjadi pada saat mereka tidur, apakah mereka akan bangun kembali dan apakah mereka akan mati [11] [2]

Dalam proses pendekatan sebelum wawancara dilakukan, peneliti berdiskusi dengan orangtua terkait perawatan yang sedang dijalani dan menceritakan perkembangan pengobatan anaknya. Dari ketujuh partisipan, satu orang mengalami relapse atau kekambuhan sehingga proses pengobatan diulangi dari tahap awal. Relapse atau kegagalan pengobatan ini adalah ketakutan yang terbesar yang dikatakan oleh anak dalam penelitian Sposito et al [9].

Perasaan lain yang ada pada partisipan adalah perasaan sedih ketika melihat orang tua. Orangtua dari partisipan sering memperlihatkan rasa khawatir di depan anak mereka dan lebih sering jika anak sedang dalam masa yang berat, mengikuti tindakan pengobatan yang menurut orang tua mengerikan, dan pada saat berdoa. Anak yang melihat tempramen orangtua yang demikian akan mempengaruhi perasaan mereka, khususnya dalam hal ketaatan melakukan prosedur pegobatan dan meminum obat [2].

Pada saat wawancara kepada partisipan, beberapa dari mereka mengeluhkan kondisi rumah sakit yang tidak kondusif. Berbagai kebisingan dan orang-orang yang tidak mereka kenal membuat mereka merasa tidak nyaman. Hal ini merupakan suatu siksaan tersendiri menurut mereka karena harus berusaha keras untuk beradaptasi agar dapat melewati masa pengobatan mereka dengan baik. Hal ini merupakan salah satu faktor penyebab stress pada saat anak dihospitalisasi. Suasana yang tidak familiar, wajah-wajah yang asing, berbagai macam bunyi dari mesin yang digunakan, dan bau yang khas, dapat menimbulkan kecemasan dan ketakutan, baik bagi anak ataupun orangtua [5]

Partisipan juga menyatakan adanya rasa bosan selama menjalani perawatan di rumah sakit dan diakui mereka sebagai akibat dari tidak adanya kegiatan yang cukup berarti selama mereka dirawat. Beberapa partisipan biasanya hanya tidur dan memainkan handphone ketika mereka merasa bosan. Anak usia sekolah merupakan anak dalam tahap tumbuh kembang yang terbiasa bergerak aktif dan bermain, mengembangkan keterampilan dan berpartisipasi dalam pekerjaan yang berguna secara sosial. Bahaya dari kondisi ini adalah adanya perasaan inferioritas pada tahap tumbuh kembang selanjutnya akibat dari ketidak tercapaian tahap tumbuh kembang pada saat ini [11].

\subsection{Kehilangan Waktu Aktifitas}

Semenjak partisipan dipastikan mengidap leukemia, mereka menjalani pengobatan dalam jangka waktu yang cukup lama di rumah sakit dan menyebabkan mereka harus mengalami perpisahan dengan orang-orang terdekat, bahkan menyebabkan anak tidak lagi dapat melakukan rutinitasnya seperti sekolah, rekreasi, belajar dan melakukan aktifitas rohani dengan leluasa.

Hal yang sama dikemukakan oleh McGrath \& Huff dalam Sposito [9] bahwa hospitalisasi dianggap sangat potensial dalam menyebabkan situasi traumatik karena perpisahan dengan lingkungan alami dan kehidupan sosial, menghadapkan anak dengan orang-orang yang tidak dikenal, rutinitas yang tidak fleksibel, peralatan medis, dan pengobatan yang agersif seperti kemoterapi.

Menurut Wong [11], anak usia sekolah mendapat dampak yang sangat besar dan signifikan dengan masuknya ke lingkungan sekolah. Kehilangan beberapa dari pola rutinitas ini khususnya sekolah sangat dikhawatirkan akan menghambat anak dalam mencapai tugas perkembangannya, sehingga sangat penting membiasakan anak dalam kegiatan akademik selama perawatan.

Pemasangan infus dan pemeriksaan sumsum tulang juga menyebabkan partisipan tidak bebas dalam bergerak bahkan untuk sekedar melakukan hal sederhana seperti menggaruk bagian tubuh yang gatal hingga melakukan permainan yang melibatkan aktivitas fisik. Kehilangan kesempatan untuk bergerak bebas ini membuat anak merasa terkekang, khususnya karena ia kehilangan kontrol atas diri dan kemandiriannya [3]. Partisipan juga menyatakan 
bahwa mereka harus membatasi aktivitas, ini dilakukan anak dengan sadar didasari pengetahuan seadanya tentang kondisi fisiknya. Pembatasan pergerakan atau aktivitas tidak hanya di sebabkan oleh tindakan prosedural medis tatapi juga orang tua partisipan yang melarang anak mereka untuk bergerak terlalu banyak karena khawatir kesehatan anaknya terganggu.

\subsection{Mengalami Perubahan Lingkungan Sosial}

Perubahan lingkungan sosial yang terjadi adalah sikap/perilaku dari teman dan orangtua serta ruang lingkup sosial anak yang melibatkan sesama pasien dan tenaga medis. Teman-teman partisipan yang ada di lingkungan rumah partisipan menunjukkan sikap yang lebih baik dan pengertian dengan kondisi partisipan, sehingga anak tetap dapat bermain jika pulang ke daerahnya dengan lebih aman. Perubahan yang dialami orangtua juga disadari oleh partisipan dimana mereka melihat orangtua mereka tidak lagi dapat menjalani aktivitas normal karena harus bersama mereka sepanjang masa perawatan. Anak juga melihat orangtua bersedih dalam beberapa kesempatan. Hal ini dinyatakan Wanda \& Hayati [11] dalam penelitiannya sebagai dampak dari hospitalisasi yang bisa bersifat positif maupun negatif.

Keterlibatan interaksi dengan sesama pasien di rumah sakit dan dengan tenaga medis merupakan bentuk dari perubahan ruang lingkup soasial anak. Menurut perkembangan psikososialnya, interaksi dengan sesama pasien merupakan hal yang wajar karena teman sebaya adalah lingkungan utama bagi anak usia sekolah sehingga dimanapun ia berada, teman sebaya merupakan orang yang cukup nyaman untuk diajak berinteraksi.

Partisipan juga mengaku memiliki hubungan yang cukup akrab dengan tenaga medis. Beberapa anak bahkan mampu menyebutkan nama petugas kesehatan di rumah sakit. Sposito [9] menyatakan hal ini merupakan bagian dari pengembangan koping anak dalam menghadapi tindakan medis. Pengenalan akan petugas kesehatan membantu anak dalam mengurangi rasa takut dan mempercayai tindakan yang diberikan adalah penting dan berpengaruh pada kesembuhannya sekalipun akan sedikit menyakitinya.

\section{Kesimpulan}

Seluruh partisipan mengalami stresor hospitalisasi yang disebabkan oleh tindakan pengobatan yang dijalani, kondisi penyakit, dan perawatan yang membutuhkan waktu lama dan berulang di rumah sakit kota Medan. Anak mengalami masa-masa yang sulit selama proses pengobatannya, namun disaat yang sama, partisipan yang merupakan anak usia sekolah menunjukkan perjuangan untuk dapat melewati proses pengobatan dengan cara mengembangkan pola koping yang baik.

Hasil penelitian ini dapat menjadi acuan dan pertimbangan bagi rumah sakit untuk meningkatkan kualitas pelayanan sesuai dengan kebutuhan pasien anak dengan leukemia khususnya dalam pemberian terapi psikologi seperti terapi bermain dan konseling pada anak dan orangtua, menciptakan lingkungan yang nyaman dan pemberian nutrisi yang sesuai bagi pasien anak leukemia.

\section{Daftar Pustaka}

[1] American Cancer Society USA.(2015). Cancer fact and figure 2015.Diakses dari http://www.carcer.org. pada tanggal 10 November 2015.

[2] Fitzgerald, Julia A. (2008). The relationship among Psychological Adaptation, Self-concept, Family Functioning anf Functional Status Among School-age Children With Acute Leukemia. Doctoral Dissertation, New York University, New York, USA.

[3] Hurlock, E.B. (1999). Psikologi Perkembangan: Suatu Pendekatan Sepanjang ruang Kehidupan. Edisi 5. Jakarta: Erlangga.

[4] Mendes, et al. (2013). Risk Factor for Mental Health Problem in School-age Children from a Community Sample.Journal of Maternal and Child Health. 17(10), 1825-1834.

[5] Norton-Westwood, D. (2012). The health care environtment through the eyes of child-Does it soot he or provoke anxiety?. International Journal of Nursing Practice, 18(1), 7-11.

[6] Permono., IDG Ugrasena. (2010). Buku Ajar Hematologi-Onkologi Anak. Jakarta: EGC.

[7] Polit, D.F., \& Beck, C.T. (2012). Nursing Research: Generating and Assesing Evidence for Nursing Practice (9th ed). Philadelphia: Lippincott

[8] Saxe, Alicia., Vieira, Luis. (2012). Topics in Well Being: Analysis of a Positive Psycholgy Exercise with Elementary School Children. Indian Journal of Positive Psychology, 3(4), 353-355. 
[9] Sposito, Amanda., et al. (2015). Coping Strategies Used by Hospitalized Children With Cancer Undergoing Chemotherapy. Journal of Nursing Scholarship. 47(2), 143-151.

[10] Tremolada, Marta., et al. (2010). Parental Perception of Health-related Qulity of Life in Children with Leukemia in The Second Week After The Diagnosis: A Quantitatif Model. Journal of Support Care Cancer, 19, 591-598

[11] Wong, D.L. (2013). Wong's Essentials Of Pediatric Nursing (9thed). St. Louis, MO: Mosby/Elsevier. 